\title{
PENGARUH INDEPENDENSI, KOMPETENSI, PENGALAMAN KERJA, DAN UKURAN KAP TERHADAP AUDIT DELAY YANG DIMEDIASI OLEH KUALTIAS AUDIT
}

\section{THE INFLUENCE OF INDEPENDENCE, COMPETENCE, WORK EXPERIENCE, AND KAP SIZE OF AUDIT DELAY MEDICATED BY AUDIT QUALITY}

\author{
Manggar Wulan Kusuma ${ }^{1}$, Prima Rosita Arini ${ }^{2}$ \\ ${ }^{1,2}$ STIE YKPN Yogyakarta \\ ${ }^{1}$ manggarwulan@gmail.com
}

\begin{abstract}
Abstrak
Laporan keuangan digunakan perusahaan untuk berkomunikasi dengan pihak internal dan eksternal dalam memberikan informasi kinerja perusahaan yang diperlukan dalam pengambilan keputusan. Perusahaan go public wajib menyampaikan laporan keuangan tahunan disertai laporan auditor independen kepada Bapepam selambat-lambatnya akhir bulan ketiga (90 hari) setelah tanggal laporan keuangan tahunan. Standar Profesional Akuntan Publik (SPAP) membuat auditor membutuhkan waktu yang tidak sebentar dalam melaksanakan audit karena harus melakukan beberapa standar supaya baik kualitas auditnya. Hal-hal tersebutlah yang menyebabkan munculnya audit delay. Apabila auditor terlalu lama melakukan kegiatan audit maka hasil laporan keuangan yang diaudit tidak relevan. Tetapi apabila auditor terburu-buru dalam melakukan tugasnya akan terjadi penurunan kualitas audit. Maka, ketepatan waktu dan profesionalitas merupakan hal-hal yang perlu diperhatikan auditor dalam melakukan tugasnya. Objek penelitian ini adalah auditor yang bekerja di KAP yang berada di Wilayah Daerah Istimewa Yogyakarta. Penelitian ini menggunakan data primer dengan menggunakan teknik analisis data analisis Partial Least Square (PLS). Hasil penelitian ini menunjukkan bahwa independensi, kompetensi, pengalaman kerja, dan ukuran KAP berpengaruh positif signifikan terhadap audit delay, dan hubungan yang terjadi antara audit delay dengan kualitas audit adalah positif dan signifikan. Hasil penelitian ini membuktikan bahwa audit delay mampu memediasi variabel independensi, kompetensi, pengalaman kerja dan ukuran KAP terhadap kualitas audit.
\end{abstract}

Kata Kunci: Independensi, Kompetensi, Pengalaman Kerja, Ukuran KAP, Audit Delay, Kualitas Audit

\begin{abstract}
The financial statements are used by companies to communicate with internal and external parties in providing company performance information needed in decision making. A publicly listed company must submit an annual financial statement accompanied by an independent auditor's report to Bapepam no later than the end of the third month (90 days) after the date of the annual financial statements. Public Accountant Professional Standards (SPAP) make auditors need time that is not short in carrying out the audit because they have to do some standards so that the audit quality is good. These are the things that cause audit delay. If the auditor takes the audit too long then the results of the audited financial statements are irrelevant. But if the auditor is in a hurry to do his job, there will be a decline in audit quality. So, punctuality and professionalism are things that need to be considered by the auditor in carrying out their duties. The object of this study was the auditor who worked at the Public Accounting Firm located in the Special Region of Yogyakarta. This study uses primary data using Partial Least Square (PLS) data analysis techniques. The results of this study indicate that independence, competence, work experience, and KAP size have a significant positive effect on audit delay, and the relationship between audit delay and audit quality is positive and significant. The results of this study prove that audit delay is able to mediate the variables of independence, competence, work experience and KAP measurement on audit quality.
\end{abstract}

Keywords: Independence, Competence, Work Experience, KAP Size, Audit Delay, Audit Quality 


\section{PENDAHULUAN}

Laporan keuangan digunakan perusahaan untuk berkomunikasi dengan pihak internal dan eksternal dalam memberikan informasi kinerja perusahaan yang diperlukan dalam pengambilan keputusan. Auditor bertugas memeriksa kewajaran laporan keuangan sehingga menumbuhkan kepercayaan penggunanya terhadap aktivitas dan kinerja perusahaan (Wiratama \& Budiartha, 2015). Perusahaan go public wajib menyampaikan laporan keuangan tahunan disertai laporan auditor independen kepada Bapepam selambat-lambatnya akhir bulan ketiga (90 hari) setelah tanggal laporan keuangan tahunan. Ketepatan waktu tergantung dari kinerja auditor dalam menyelesaikan pekerjaannya (Kartika, 2009). Perbedaan waktu antara tanggal laporan keuangan dengan tanggal opini audit disebut audit delay dan mengindikasikan seberapa lama auditor melakukan audit (Kartika, 2011). Standar Profesional Akuntan Publik (SPAP) membuat auditor membutuhkan waktu yang tidak sebentar dalam melaksanakan audit karena harus melakukan beberapa standar supaya baik kualitas auditnya. Hal-hal tersebutlah yang menyebabkan munculnya audit delay (Ashton et.al, 1987). Independensi memiliki hubungan positif dengan kualitas audit. Penelitian yang dilakukan Badjuri (2011), Suyono (2012), Salim (2012), Agusti dan Pertiwi (2013), dan Suharti et.al (2017) membuktikan hal tersebut. Kompetensi adalah kualifikasi yang dibutuhkan auditor untuk melakukan tindakan audit dengan tepat. Menurut Alim et.al (2007) dan Salim, et al., (2012) kompetensi memiliki pengaruh positif terhadap kualitas audit. Auditor yang berpengalaman menghasilkan laporan audit berkualitas baik karena kemampuannya menghadapi masalah yang mungkin muncul pada laporan keuangan klien. Terbukti dengan hasil penelitian oleh Samsi (2013) dan Wiratama dan Budiartha (2015). Ukuran KAP mempengaruhi kualitas audit. Hasil penelitian Choi, et.al (2010), Yuliana dan Hapsari (2013) dan Aronmwan (2013) membuktikan semakin besar ukuran KAP akan semakin baik kualitas auditnya. Penelitian ini menggabungkan beberapa faktor yang mempengaruhi audit delay. Dalam berbagai penelitian faktor yang mempengaruhi audit delay dijelaskan secara terpisah. Penelitian ini menggabungkan beberapa faktor yang diuji secara terpisah tersebut untuk dilihat lebih lanjut diantara berbagai faktor tersebut, faktor manakah yang memiliki pengaruh terkuat terhadap audit delay. Selain itu dalam penelitian terdahulu, kualitas audit merupakan variabel independen dalam suatu penelitian yang meneliti tentang hubungannya dengan audit delay, namun dalam penelitian ini, peneliti ingin melihat apakah kualitas audit mampu memediasi hubungan antara faktorfaktor yang mempengaruhi audit delay.

\section{Tujuan Penelitian}

Penelitian ini bertujuan untuk: mengetahui pengaruh independensi auditor terhadap kualitas audit, mengetahui pengaruh kompetensi auditor terhadap kualitas audit, mengetahui pengaruh pengalaman kerja auditor terhadap kualitas audit, mengetahui pengaruh ukuran KAP terhadap kualitas audit dan bagaimana pengaruh kualitas audit terhadap audit delay.

\section{Kajian Teori Dan Pengembangan Hipotesis Kajian Teori}

Mulyadi (2002) mendefinisikan independensi sebagai suatu sikap mental yang bebas dari pengaruh, tidak dikendalikan dan tergantung pihak lain. Independensi sebagai sebuah cara pandang yang tidak memihak didalam pelaksanaan pengujian evaluasi hasil pemeriksaan, dan penyusunan laporan audit (Arens, 2006). Independensi sangat penting bagi profesi akuntan publik karena merupakan dasar bagi akuntan publik untuk merumuskan dan menyatakan pendapat yang dapat dipercaya oleh masyarakat atas laporan keuangan yang diperiksa (Hardiningsih, 2010).

Lee dan Stone (1995) mendefinisikan kompetensi sebagai sebuah keahlian yang secara eksplisit digunakan untuk melakukan audit secara objektif. Kompetensi auditor adalah kualifikasi yang dibutuhkan auditor untuk melaksanakan audit dengan benar, dan seorang auditor harus memiliki mutu personal yang baik, pengetahuan yang memadai, serta keahlian khusus dibidangnya (Rai, 2008). Arens et al. (2008) menyatakan bahwa auditor harus memiliki kualifikasi untuk memahami kriteria yang digunakan dan berkompeten untuk mengetahui jenis serta jumlah bukti yang akan dikumpulkan guna mencapai kesimpulan yang tepat setelah memeriksa bukti tersebut.

Menurut SPAP Tahun 2011, pengalaman kerja yaitu auditor dalam melaksanakan audit hingga sampai pada suatu pernyataan pendapat harus bertindak sebagai seorang ahli dalam bidang akuntansi 
dan auditing. Mulyadi (2002) menegaskan bahwa seorang auditor harus mempunyai pengalaman dalam kegiatan auditnya, pendidikan formal dan pengalaman kerja dalam profesi akuntan merupakan dua hal penting dan saling melengkapi.

Menurut PMK No.17 Tahun 2008 Pasal 1, Akuntan Publik adalah akuntan yang telah memperoleh izin dari Menteri untuk memberikan jasa sebagaimana diatur. Perusahaan akan mencari KAP yang berkredibilitas tinggi untuk meningkatkan kredibilitas laporan keuangan di mata pemakai laporan keuangan Halim (1997). DeAngelo (1981) menunjukkan KAP berukuran besar umumnya dianggap sebagai penyedia kualitas audit yang tinggi dan menikmati reputasi tinggi dalam lingkungan bisnis dan karena itu, akan berusaha untuk mempertahankan independensi untuk menjaga image mereka.

Menurut DeAngelo (1981), kualitas audit sebagai probabilitas seorang auditor dalam menentukan dan melaporkan penyelewengan yang terjadi dalam sistem akuntansi klien. Temuan pelanggaran pengukuran kualitas audit berkaitan dengan pengetahuan dan keahlian auditor (DeAngelo, 1981). Lee, Liu, dan Wang (1999) berpendapat kualitas audit sebagai probabilitas bahwa auditor tidak akan melaporkan laporan audit dengan opini wajar tanpa pengecualian untuk laporan keuangan yang mengandung kekeliruan material.

Ashton et.al (1987) mengartikan audit delay sebagai lamanya waktu penyelesaian audit yang diukur dari tanggal penutupan tahun buku sampai dengan tanggal diterbitkannya laporan audit. Audit delay adalah lamanya waktu penyelesaian pelaksanaan audit dari akhir tahun fiskal perusahaan sampai dengan tanggal laporan audit dikeluarkan (Kartika, 2009).

\section{Pengembangan Hipotesis}

\section{Pengaruh Independensi Terhadap Kualitas Audit}

Nilai dari suatu proses pengauditan tergantung pada independensi auditor itu sendiri (Arens,2010). Seorang auditor dituntut memiliki kejujuran yang tinggi dan melakukan audit secara obyektif tidak memihak manapun. Mayangsari (2003) membuktikan independensi berpengaruh signifikan terhadap pendapat audit yang dihasilkan oleh auditor. Triningisih (2007) menyimpulkan jika seorang auditor menjaga sikap independen maka akan menambah kredibilitas laporan keuangan yang disajikan. Independensi berpengaruh signifikan terhadap kualitas audit (Alim, 2007). Berdasarkan pernyataan ini maka dibentuk hipotesis pertama.

Hipotesis 1 : Independensi berpengaruh terhadap Kualitas Audit.

\section{Pengaruh Kompetensi Terhadap Kualitas Audit}

Auditor berkompeten adalah auditor yang memiliki pengalaman yang cukup (Nugraha, 2012). Auditor berpengalaman akan lebih mudah mengetahui berbagai masalah secara lebih mendalam. Semakin tinggi tingkat kompetensi seorang auditor diharapkan akan semakin tinggi pula tingkat kualitas audit yang dihasilkan. Christiawan (2002) membuktikan semakin tinggi kompetensi auditor semakin baik kualitas hasil pemeriksaannya. Alim (2007) juga membuktikan kompetensi merupakan faktor penting yang mempengaruhi kualitas audit. Dengan demikian maka dibentuk hipotesis kedua. Hipotesis 2 : Kompetensi Berpengaruh Terhadap Kualitas Audit.

\section{Pengaruh Pengalaman Kerja Terhadap Kualitas Audit}

Auditor yang berpengalaman akan banyak menemukan item-item yang tidak umum jika dibandingkan dengan auditor yang kurang atau yang tidak memiliki pengalaman (Indah , 2010). Auditor yang tidak berpengalaman akan cenderung melakukan atribusi kesalahan lebih besar dibandingkan dengan auditor yang berpengalaman. Sawyer (2009) membuktikan bahwa pengalaman berpengaruh signifikan terhadap kinerja auditor. Semakin banyak pengalaman seorang auditor dalam melakukan pemeriksaan, maka semakin baik pula kinerjanya. Berdasarkan pernyataan ini, maka dibentuk hipotesis ketiga.

Hipotesis 3 : Pengalaman Kerja Berpengaruh Terhadap Kualitas Audit.

\section{Pengaruh Ukuran KAP Terhadap Kualitas Audit}

DeAngelo (1981) menunjukkan KAP yang lebih besar umumnya dianggap sebagai penyedia kualitas audit yang tinggi. KAP berukuran besar memiliki tingkat ketergantungan secara ekonomis 
yang lebih kecil daripada KAP berukuran kecil, sehingga KAP besar tidak terlalu bergantung pada klien tertentu. Pernyataan ini mendukung penelitian Francis dan Yu (2009), semakin besar ukuran KAP maka kualitas audit yang dihasilkan akan semakin tinggi. Penelitian Choi et al. (2010) dan Aronmwan (2013) membuktikan bahwa ukuran KAP berimplikasi signifikan terhadap kualitas audit. Berdasarkan pernyataan ini,maka dibentuk hipotesis keempat.

Hipotesis 4: Ukuran KAP Berpengaruh Terhadap Kualitas Audit.

\section{Pengaruh Kualitas Audit Terhadap Audit Delay}

Informasi keuangan dan kinerja perusahaan akan lebih dapat dipercaya apabila telah menggunakan jasa KAP (Saputri, 2012). Perusahaan memerlukan auditor yang berkualitas tinggi, agar kualitas laporan keuangan yang diaudit bagus. Tetapi untuk mengaudit laporan keuangan secara benar dan hasil auditnya bagus maka membutuhkan waktu yang cukup. Semakin baik kualitas audit yang diinginkan, maka terjadi audit delay. Rentang waktu penyelesaian audit yang lebih cepat adalah cara KAP untuk mempertahankan reputasinya agar tidak kehilangan kepercayaan klien (Sunangsih, 2014). Berdasarkan pernyataan diatas, maka dibentuk hipotesis kelima.

Hipotesis 5: Kualitas Audit Berpengaruh Terhadap Audit Delay

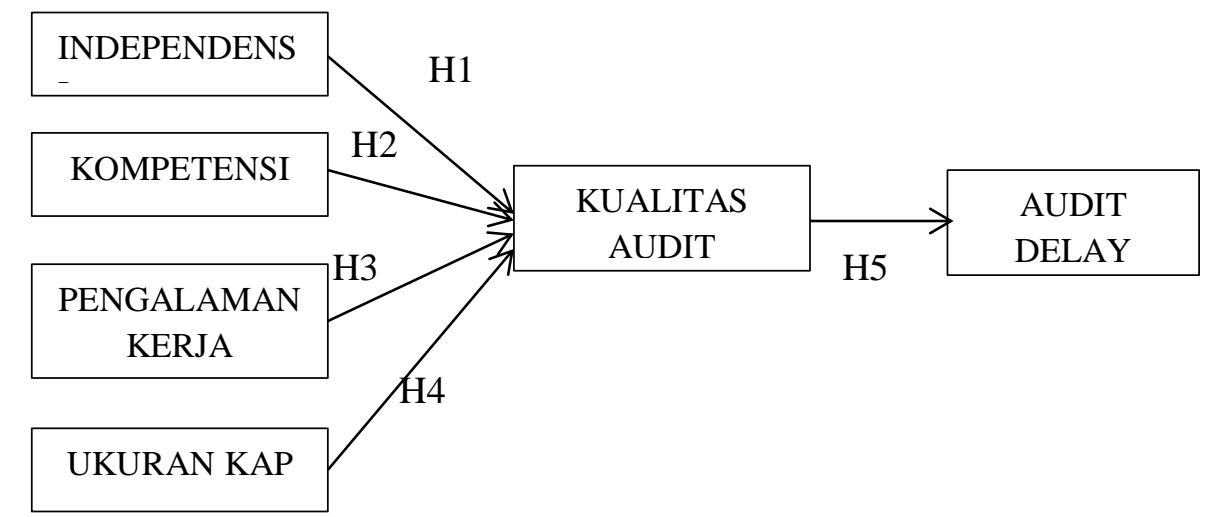

Keterangan:

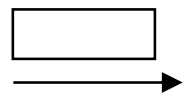

: Indikator
: Pengaruh Variabel

Gambar 1. Kerangka Pemikiran

\section{METODE}

\section{Sumber dan Data Penelitian}

Jenis data yang digunakan dalam penelitian ini adalah data primer. Data primer adalah Data yang diambil adalah data primer yang merupakan data yang diperoleh secara langsung dari para responden yaitu mahasiswa di DIY, khusus untuk mencapai tujuan penelitian. Data dikumpulkan melalui kuisioner yang disebarkan dan diukur menggunakan skala Likert 1 sampai dengan 5 (1= sangat setuju dan $5=$ sangat tidak setuju).

\section{Sampel dan Tempat Penelitian}

Teknik atau prosedur pengambilan sampel dalam penelitian ini adalah purposive sampling. Sampel penelitian diambil berdasarkan kriteria tertentu. Pada penelitian ini, yang menjadi sampel penelitian adalah mahasiswa yang telah menempuh mata kuliah pengauditan khususnya mahasiswa Pendidikan Profesi Akuntansi dan mahasiswa Magister Akuntansi yang berkuliah di Daerah Istimewa Yogyakarta.

\section{Variabel dan Definisi Operasional}

Klasifikasi variabel didasarkan atas kajian teoritis dan empiris sebagai acuan kerangka berfikir yang terdiri dari dua variabel: 


\section{Variabel Eksogen}

Variabel yang mempengaruhi operasi dalam suatu model ekonomi dan tidak dipengaruhi oleh setiap hubungan yang digambarkan oleh model tersebut. Variabel Eksogen dalam penelitian ini adalah Independensi (X1), Kompetensi (X2), Pengalaman Kerja (X3), Ukuran KAP (X4).

\section{Variabel Endogen}

Variabel endogen adalah variabel yang dipengaruhi oleh variabel eksogen. Variabel endogen dalam penelitian ini adalah:

a. Variabel endogen intervening

Variabel yang ikut berpengaruh ketika variabel eksogen mempengaruhi variabel endogen tergantung. Variabel endogen intervening dalam penelitian ini adalah Kualitas Audit (Y1).

b. Variabel endogen tergantung

Variabel yang dipengaruhi oleh variabel eksogen maupun variabel endogen intervening. Variabel endogen tergantung dalam penelitian ini adalah Audit Delay (Y2).

\section{Definisi Operasional Variabel \\ Independensi}

Mulyadi (2002) mendefinisikan independensi sebagai suatu sikap mental yang bebas dari pengaruh, tidak dikendalikan dan tergantung pihak lain. Dalam penelitian ini independensi auditor diukur menggunakan indikator yang dibuat oleh Trisnaningsih (2007).

\section{Kompetensi}

Kompetensi auditor adalah kualifikasi yang dibutuhkan auditor untuk melaksanakan audit dengan benar, dan seorang auditor harus memiliki mutu personal yang baik, pengetahuan yang memadai, serta keahlian khusus dibidangnya (Rai,2008). Kompetensi diukur dengan pencapaian kompetensi profesional dan pemeliharaan kompetensi profesional.

\section{Pengalaman Kerja}

Menurut SPAP Tahun 2011, pengalaman kerja yaitu auditor dalam melaksanakan audit hingga sampai pada suatu pernyataan pendapat harus bertindak sebagai seorang ahli dalam bidang akuntansi dan auditing. Pengalaman kerja diukur dengan menggunakan 3 indikator yaitu mendeteksi kesalahan, memahami kesalahan secara akurat, dan mencari penyebab kesalahan.

\section{Ukuran KAP}

Menurut PMK No.17 Tahun 2008 Pasal 1, Akuntan Publik adalah akuntan yang telah memperoleh izin dari Menteri untuk memberikan jasa sebagaimana diatur. Variabel ini diukur berdasarkan indikator yang dibuat oleh Sawan dan Al-Saqqa (2013).

\section{Kualitas Audit}

Menurut DeAngelo (1981), kualitas audit sebagai probabilitas seorang auditor dalam menentukan dan melaporkan penyelewengan yang terjadi dalam sistem akuntansi klien. Pengukuran variabel ini diadopsi dari penelitian Harhinto (2004).

\section{Audit Delay}

Ashton et.al (1987) mengartikan audit delay sebagai lamanya waktu penyelesaian audit yang diukur dari tanggal penutupan tahun buku sampai dengan tanggal diterbitkannya laporan audit. Variabel ini diukur menggunakan 2 indikator yaitu penutupan tahun buku dan penerbitan laporan audit.

\section{HASIL DAN PEMBAHASAN \\ Hasil Uji Validitas Data}

Metode yang digunakan peneliti untuk mengumpulkan data dalam penelitian ini adalah dengan menyebarkan kuisioner kepada responden. Pada penelitian ini jumlah responden yang ada pada 
penelitian ini adalah sebanyak 79 responden. Responden yang digunakan dalam penelitian ini adalah auditor yang berada di wilayah kota Yogyakarta. Berdasarkan hasil sebaran kuisioner maka diperoleh hasil sebagai berikut:

Tabel 1. Tabel Demografi Responden

\begin{tabular}{llcc}
\hline \multicolumn{2}{c}{ Karakteristik } & Jumlah Responden & Persentase \\
\hline Gender: & Laki-laki & 42 & $53 \%$ \\
& Perempuan & 37 & $47 \%$ \\
Usia & $21-30$ & 71 & $90 \%$ \\
& $31-40$ & 8 & $10 \%$ \\
Masa Kerja & & 24 & $30 \%$ \\
& 1 Tahun & 19 & $24 \%$ \\
& 2 Tahun & 8 & $10 \%$ \\
& 3 Tahun & 28 & $35 \%$ \\
\hline
\end{tabular}

Sumber: Data Diolah

Berdasarkan hasil penyebaran kuisioner yang telah dilakukan oleh peneliti, terlihat bahwa yang menjadi responden dalam penelitian ini sebagian besar merupakan auditor yang berjenis kelamin laki-laki yang ditunjukkan dengan persentase sebesar 53\%. Selain itu dari segi usia, terlihat bahwa usia yang mendominasi dalam penelitian ini adalah auditor yang berusia antara 21-30 tahun yang dapat dilihat pada hasil demografi responden yaitu sebesar $90 \%$. Apabila dipandang dari sudut masa kerja auditor tersebut maka terlihat bahwa yang menjadi responden dalam penelitian ini sebagian besar sudah memiliki pengalaman menjadi auditor selama lebih dari 3 tahun yang ditunjukkan dengan nilai persentase sebesar $35 \%$.

\section{Statistika Deksriptif}

Tabel 2. Tabel Statistik Deskriptif

\begin{tabular}{llllll}
\hline Variabel & N & Rata-rata & Minimum & Maksimum & $\begin{array}{l}\text { Standar } \\
\text { Deviasi }\end{array}$ \\
\hline Pengalaman Kerja & 79 & 3,92 & 1 & 5 & 0,64 \\
Independensi & 79 & 3,87 & 1 & 5 & 0,66 \\
Ukuran KAP & 79 & 3,78 & 1 & 5 & 0,74 \\
Kompetensi & 79 & 4,01 & 1 & 5 & 0,71 \\
Kualitas Audit & 79 & 4,00 & 1 & 5 & 0,69 \\
Audit Delay & 79 & 3,71 & 1 & 5 & 0,85 \\
\hline
\end{tabular}

Sumber: Data Diolah

Selain data demografi, pada penelitian ini peneliti juga melakukan penghitungan untuk statistika deskriptif. Berdasarkan pengolahan data yang dimiliki oleh peneliti maka diperoleh hasil bahwa untuk variabel pengalaman kerja rata-rata responden memberikan jawaban pada angka 3,92 yang mengarah pada pernyataan setuju untuk setiap butir pernyataan atau pertanyaan yang diberikan dan memiliki standar deviasi sebesar 0,64. Untuk variabel independensi, diperoleh hasil bahwa ratarata responden memberikan jawaban pada angka 3,87 yang mengarah pada angka 4 yang menunjukkan pernyataan setuju untuk setiap butir pernyataan atau pertanyaan yang diberikan, sedangkan nilai untuk standar deviasi adalah sebesar 0,66. Variabel lain yang diuji adalah variabel ukuran KAP. Berdasarkan hasil yang diperoleh maka terlihat bahwa rata-rata jawaban responden adalah sebesar 3,78 yang menunjukkan bahwa responden memberikan pernyataan setuju untuk setiap item pernyataan atau pertanyaan yang diberikan. Untuk hasil standar deviasi diperoleh hasil sebesar 0,74. Begitu pula untuk variabel kompetensi, dalam penelitian ini rata-rata jawaban yang diberikan 
oleh responden adalah 4,01 yang menunjukkan bahwa responden menyatakan bahwa mereka setuju untuk setiap item pernyataan atau pertanyaan yang diberikan pada kuisioner, sedangkan untuk standar deviasi diperoleh hasil sebesar 0,71. Selain itu, untuk variabel kualitas audit diperoleh hasil bahwa rata-rata jawaban responden adalah pada angka 4,00 yang menyatakan setuju pada setiap butir pernyataan atau pertanyaan yang diberikan dalam kuisioner tersebut dan untuk nilai standar deviasi ditunjukkan dengan nilai 0,69. Variabel dependen dalam penelitian ini yaitu variabel audit delay memiliki nilai rata-rata jawaban responden yaitu sebesar 3,71 yang memiliki arti bahwa rata-rata jawaban para responden mengarah pada jawaban setuju dan untuk nilai standar deviasi ditunjukkan dengan nilai sebesar 0,85 .

Uji Validitas dan Uji Reliabilitas

Tabel 3. Tabel Uji Validitas

\begin{tabular}{|c|c|c|c|c|c|c|c|c|}
\hline & PK & ID & KP & UK & KUAL & AD & SE & P value \\
\hline \multicolumn{9}{|l|}{$\begin{array}{l}\text { AVE PK = } \\
0.550\end{array}$} \\
\hline PK_1 & 0.761 & 0.312 & 0.046 & -0.723 & 0.787 & -0.01 & 0.083 & $<0.001$ \\
\hline PK_2 & 0.796 & -0.162 & 0.212 & -1.191 & 1.054 & 0.584 & 0.083 & $<0.001$ \\
\hline $\mathrm{PK}_{-} 3$ & 0.738 & -0.44 & -0.932 & 0.612 & 0.16 & 0.088 & 0.083 & $<0.001$ \\
\hline $\mathrm{PK}_{-} 4$ & 0.799 & -0.055 & 0.369 & 1.111 & -1.199 & -0.269 & 0.083 & $<0.001$ \\
\hline PK_6 6 & 0.771 & 0.116 & -0.13 & 0.42 & 0.219 & -0.346 & 0.083 & $<0.001$ \\
\hline $\mathrm{PK}_{-} 7$ & 0.557 & 0.306 & 0.519 & -0.293 & -1.378 & -0.074 & 0.083 & $<0.001$ \\
\hline \multicolumn{9}{|c|}{$\begin{array}{l}\text { AVE ID = } \\
0,578\end{array}$} \\
\hline ID_1 & -0.4 & 0.819 & 1.129 & -0.07 & -0.968 & 0.149 & 0.083 & $<0.001$ \\
\hline ID_2 & 0.34 & 0.854 & -0.564 & 0.481 & 0.21 & -0.223 & 0.083 & $<0.001$ \\
\hline ID_3 & 0.848 & 0.758 & -0.067 & -0.389 & -0.459 & -0.033 & 0.083 & $<0.001$ \\
\hline ID_4 & -0.987 & 0.582 & -0.43 & -1.668 & 2.741 & 0.578 & 0.083 & $<0.001$ \\
\hline ID_5 & -0.043 & 0.761 & -0.185 & 1.199 & -0.833 & -0.32 & 0.083 & $<0.001$ \\
\hline \multicolumn{9}{|c|}{$\begin{array}{l}\mathrm{AVE} \mathrm{KP}= \\
0.633\end{array}$} \\
\hline $\mathrm{KP} \_2$ & -0.947 & 0.137 & 0.719 & -0.324 & 0.136 & 0.465 & 0.083 & $<0.001$ \\
\hline KP_4 & 0.328 & -0.12 & 0.904 & 0.104 & 0.478 & -0.127 & 0.083 & $<0.001$ \\
\hline KP_5 & 1.158 & 0.043 & 0.593 & -0.064 & -0.961 & -0.233 & 0.083 & $<0.001$ \\
\hline KP_6 & 0.132 & 0.3 & 0.828 & 0.961 & -1.378 & -0.204 & 0.083 & $<0.001$ \\
\hline KP_7 & 0.133 & -0.279 & 0.916 & -0.119 & 0.861 & -0.045 & 0.083 & $<0.001$ \\
\hline $\mathrm{KP}_{-}^{-} 10$ & -0.697 & -0.012 & 0.765 & -0.667 & 0.514 & 0.168 & 0.083 & $<0.001$ \\
\hline \multicolumn{9}{|c|}{$\begin{array}{l}\text { AVE UK } \\
=0,515\end{array}$} \\
\hline UK_1 & -0.532 & 0.001 & 0.533 & 0.562 & 0.164 & 0.637 & 0.083 & $<0.001$ \\
\hline UK_2 & -0.177 & 0.475 & 0.639 & 0.508 & -0.94 & 0.649 & 0.083 & $<0.001$ \\
\hline UK_3 & -0.174 & 0.239 & 0.436 & 0.816 & -0.485 & 0.484 & 0.083 & $<0.001$ \\
\hline UK_4 & 0.611 & -0.097 & -0.195 & 0.884 & -0.725 & -0.247 & 0.083 & $<0.001$ \\
\hline UK_6 & -0.159 & 0.187 & -0.334 & 0.741 & -0.116 & -0.507 & 0.083 & $<0.001$ \\
\hline UK_7 & 0.535 & -0.34 & -0.52 & 0.681 & 0.592 & -0.52 & 0.083 & $<0.001$ \\
\hline UK_8 & -0.336 & -0.344 & -0.274 & 0.757 & 1.463 & -0.181 & 0.083 & $<0.001$ \\
\hline \multicolumn{9}{|l|}{ AVE } \\
\hline \multicolumn{9}{|l|}{ KUAL = } \\
\hline KUAL_1 & 0.395 & 0.054 & -0.362 & -0.114 & 0.858 & -0.187 & 0.083 & $<0.001$ \\
\hline KUAL_3 & -0.264 & 0.312 & -0.055 & 0.268 & 0.815 & -0.037 & 0.083 & $<0.001$ \\
\hline KUAL_4 & -0.511 & 0.218 & 0.122 & -0.029 & 0.879 & 0.004 & 0.083 & $<0.001$ \\
\hline KUAL_5 & -0.059 & -0.321 & 0.049 & -0.848 & 0.832 & 0.142 & 0.083 & $<0.001$ \\
\hline KUAL_6 & -0.277 & -0.106 & -0.409 & 0.551 & 0.86 & -0.325 & 0.083 & $<0.001$ \\
\hline KUAL_7 & -0.172 & -0.013 & 0.4 & 0.773 & 0.825 & 0.088 & 0.083 & $<0.001$ \\
\hline
\end{tabular}




\begin{tabular}{lllllllll}
\hline KUAL_8 & 0.786 & -0.032 & 0.179 & -0.162 & 0.738 & 0.111 & 0.083 & $<0.001$ \\
KUAL_9 & 0.731 & 0.077 & -0.664 & -0.196 & 0.646 & 0.15 & 0.083 & $<0.001$ \\
KUAL_10 & -0.357 & -0.181 & 0.631 & -0.307 & 0.834 & 0.116 & 0.083 & $<0.001$ \\
AVE = & & & & & & & & \\
0,670 & & & & & & & & \\
AD_2 & 0.135 & -0.38 & -0.148 & -0.266 & 0.631 & 0.807 & 0.083 & $<0.001$ \\
AD_3 & 0.568 & 0.354 & -0.227 & 0.94 & -1.509 & 0.819 & 0.083 & $<0.001$ \\
AD_4 & -0.466 & 0.295 & 0.732 & -0.563 & 0.046 & 0.88 & 0.083 & $<0.001$ \\
AD_5 & 0.007 & -0.115 & -0.753 & 0.436 & 0.289 & 0.89 & 0.083 & $<0.001$ \\
AD_6 & 0.372 & -0.335 & -1.071 & 0.459 & 0.088 & 0.657 & 0.083 & $<0.001$ \\
AD_8 & -0.164 & -0.158 & 0.094 & -0.299 & 0.351 & 0.953 & 0.083 & $<0.001$ \\
AD_9 & 0.379 & -0.017 & 0.338 & -0.293 & -0.1 & 0.77 & 0.083 & $<0.001$ \\
AD_10 & -0.752 & 0.333 & 0.936 & -0.327 & 0.155 & 0.731 & 0.083 & $<0.001$ \\
\hline
\end{tabular}

Sumber: Data Diolah

Penelitian ini menggunakan data primer, dalam hal ini kuisioner digunakan sebagai alat untuk mengumpulkan data. Oleh karena itu pengujian kualitas data diperlukan. Salah satu uji kualitas data adalah dengan melakukan uji validitas, berdasarkan data yang berada pada tabel pengujian validitas terlihat bahwa semua indikator yang digunakan untuk mengukur variabel sudah valid. Validitas tersebut juga didukung dengan nilai AVE yang diatas 0,5 untuk semua variabel yang digunakan dalam penelitian ini.

Tabel 4. Tabel Pengujian Reliabilitas

\begin{tabular}{lllllll}
\hline & PK & ID & KP & UK & KUAL & AD \\
\hline Cronbach's Alpha & 0.833 & 0.813 & 0.878 & 0.835 & 0.934 & 0.927 \\
\hline Sumber: Data Diolah & & & & & &
\end{tabular}

Sumber: Data Diolah

Tidak hanya validitas, untuk pengujian kualitas data juga diperlukan adanya uji reliabilitas yang ditunjukkan dengan nilai Cronbach's Alpha. Berdasarkan uji reliabilitas yang telah dilakukan oleh peneliti diperoleh hasil bahwa untuk semua variabel yang digunakan dalam penelitian ini sudah reliable. Hal tersebut ditunjukkan dengan nilai Cronbach's alpha yang lebih besar dari 0,8.

\section{Pengujian Hipotesis}

Sumber: Data Diolah

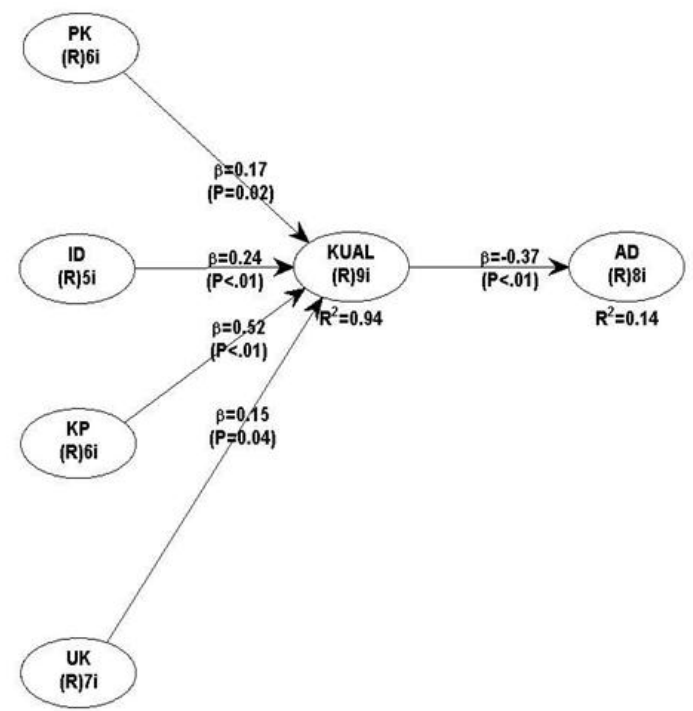

Gambar 2. Hasil Olah Data 


\section{Pembahasan}

\section{Independensi Berpengaruh Positif Terhadap Kualitas Audit}

Pengujian hipotesis yang dilakukan dalam penelitian ini adalah dengan menggunakan alat statistik SEM-PLS yang ditunjukkan pada gambar pengujian hipotesis. Berdasarkan pengujian hipotesis untuk mengetahui hubungan antara independensi dan kualitas audit diperoleh hasil bahwa arah hubungan yang terjadi adalah positif dan signifikan. Hal tersebut ditunjukkan dengan nilai koefisien sebesar 0,24 dan nilai $p$-value sebesar $<0.01$. Penelitian ini sesuai dengan penelitian yang telah dilakukan oleh Triningisih (2007) dan Alim (2007) yang memiliki kesimpulan bahwa tingkat independensi memiliki pengaruh yang positif dan signifikan terhadap kualitas audit. Independensi adalah sifat yang harus dimiliki oleh seorang auditor agar setiap opini yang diberikan tidak memihak pada salah satu pihak. Arah positif ini menunjukkan bahwa jika auditor bersikap independen dalam pekerjaannya maka semakin baik kualitas audit yang dihasilkan, sehingga klien akan yakin bahwa informasi yang disajikan itu kredibel atau dapat dipercaya. Berdasarkan PSA No.04 (SA 220), auditor harus bersikap independen yang memiliki arti tidak mudah untuk dipengaruhi, karena auditor melaksanakan pekerjaannya untuk kepentingan umum (Siregar et. al., 2011). Sudah terdapat beberapa kasus yang terjadi dikarenakan tidak adanya sikap independensi dalam diri seorang auditor. Salah satunya kasus yang menimpa akuntan publik Justinus Aditya Sidharta yang dijadikan sebagai tersangka oleh Bapepam karena telah terbutki melakukan kesalahan dalam mengaudit laporan keuangan milik PT.Great River Internasional, Tbk, sehingga menyebabkan kerugian yang besar terhadap perusahaan tersebut. Oleh karena itu, sikap independensi ini mutlak harus ada pada diri auditor ketika ia melakukan audit karena apa yang dilakukan oleh auditor tersebut tentunya akan mempengaruhi kualitas audit yang dibuatnya (Wijayani dan Indira, 2011). Berdasarkan hasil pengujian hipotesis dan kesesuaian dengan penelitian terdahulu maka diputuskan bahwa itu hipotesis satu dapat diterima.

\section{Kompetensi Berpengaruh Positif Terhadap Kualitas Audit}

Hasil pengujian hipotesis yang kedua dilakukan untuk melihat hubungan antara kompetensi dan kualitas audit. Berdasarkan hasil analisis, diperoleh hasil bahwa pengaruh antara kompetensi dan kualitas audit adalah positif dan signifikan. Hal tersebut ditunjukkan dengan nilai koefisien sebesar 0,52 dan $p$-value sebesar $<0,01$. Hal tersebut memiliki arti bahwa semakin tinggi tingkat kompetensi seorang auditor maka kualitas audit yang ada juga akan semakin baik. Christiawan (2002) membuktikan bahwa semakin tinggi kompetensi auditor maka akan semakin baik kualitas hasil pemeriksaannya. Alim (2007) juga membuktikan kompetensi merupakan faktor penting yang mempengaruhi kualitas audit. Hal ini berarti bahwa kualitas audit dapat dicapai jika auditor memiliki kompetensi yang baik. Adanya kompetensi yang baik menunjukkan bahwa kemampuan yang dimiliki oleh auditor tersebut juga baik. Pada tahun 2018 Otoritas Jasa Keuangan (OJK) menjatuhkan sanksi kepada Akuntan Publik Marlinna dan Akuntan Publik Merliyana Syamsul serta KAP Satrio, Bing, Eny (SBE) karena dinilai tidak memiliki kompetensi dalam pekerjaanya sehingga tidak memberikan opini yang sesuai dengan kondisi yang sebenarnya dalam laporan keuangan tahunan audit milik PT.Sunprima Nusantara Pembiayaan (SNP Finance). Hasil penelitian ini sesuai dengan Elfarini (2007), Alim (2007) dan Castellani (2008) bahwa kompetensi berpengaruh terhadap kualitas audit. Berdasarkan hasil pengujian hipotesis dan kesesuaian dengan penelitian sebelumnya maka dapat diputuskan bahwa hipotesis kedua dapat diterima.

\section{Pengalaman Kerja Berpengaruh Positif Terhadap Kualitas Audit}

Pengalaman kerja memiliki peran yang penting dan berhubungan dengan kualitas audit. Oleh karena itu, hubungan antara pengalaman kerja dan kualitas audit diuji pada hipotesis ketiga dan diperoleh hasil bahwa pengalaman kerja memiliki hubungan yang positif dan signifikan terhadap kualitas audit. Hal tersebut didukung dengan hasil pengujian yang menunjukkan nilai koefisien sebesar 0,17 dan p-value sebesar 0,02. Hasil pengujian hipotesis ini sesuai dengen teori yang menyatakan bahwa auditor yang berpengalaman akan banyak menemukan item-item yang tidak umum jika dibandingkan dengan auditor yang kurang atau yang tidak memiliki pengalaman (Indah, 2010). Semakin banyak pengalaman yang dimiliki seorang auditor dalam melakukan pemeriksaan, maka akan semakin baik pula kinerjanya. Kinerja yang dimiliki oleh auditor tentunya berhubungan 
dengan kualitas audit yang dibuatnya. Auditor sebagai ujung tombak pelaksanaan tugas audit memang harus senantiasa meningkatkan pengetahuan yang telah dimiliki agar penerapan pengetahuan dapat maksimal dalam praktiknya. Pengalaman kerja tentunya juga akan memberikan dampak pada setiap keputusan yang harus diambil dalam pelaksanaan audit sehingga diharapkan setiap keputusan yang diambil merupakan keputusan yang tepat. Bagi para auditor junior yang tentunya memiliki pengalaman kerja lebih sedikit dibandingkan dengan auditor senior, akan berpotensi melakukan kesalahan pemberian opini di dalam pembuatan laporan auditnya. Hal ini bisa disebabkan karena auditor junior masih memiliki pengalaman yang sedikit dan biasanya masih mengikuti beberapa training atau pelatihan yang dilaksanakan KAP tempat dia bekerja. Hal tersebut mengindikasikan bahwa semakin lama masa kerja yang dimiliki auditor maka auditor akan semakin baik pula kualitas audit yang dihasilkan (Alim, 2007). Berdasarkan hasil analisis data dan penelitian terdahulu maka hipotesis ketiga dapat diterima.

\section{Ukuran KAP Berpengaruh Positif Terhadap Kualitas Audit}

Pengujian hipotesis yang keempat dilakukan untuk menguji hubungan yang terjadi antara ukuran KAP dan kualitas audit. Berdasarkan hasil pengujian yang telah dilakukan oleh peneliti, diperoleh hasil bahwa ukuran KAP memiliki pengaruh yang positif dan signifikan terhadap kualitas audit. Hal ini dapat dilihat dari nilai koefisien yang ada yaitu sebesar 0,15 dan nilai $p$-value sebesar 0,04 . Hasil tersebut memiliki makna bahwa semakin besar ukuran KAP maka kualitas audit yang dihasilkan juga akan semakin baik. Hasil tersebut sesuai dengan penelitian yang dilakukan Sawan dan Ihab (2012) yang menyatakan bahwa kualitas audit yang dibuat oleh KAP yang masuk dalam Big Four berbeda dengan yang tidak masuk dalam kelompok Big Four. KAP yang memiliki ukuran besar khususnya yang tergolong dalam Big Four lebih dipercaya oleh masyarakat untuk hasil audit yang mereka buat karena kualitas audit yang dimiliki menurut pengguna laporan keuangan tersebut dianggap baik. DeAngelo (1981) menunjukkan bahwa KAP yang lebih besar umumnya dianggap sebagai penyedia kualitas audit yang tinggi. KAP berukuran besar memiliki tingkat ketergantungan secara ekonomis yang lebih kecil daripada KAP berukuran kecil, sehingga KAP besar tidak terlalu bergantung pada klien tertentu. Hasil penelitian ini sesuai dengan penelitian Francis dan Yu (2009) yang menyatakan bahwa semakin besar ukuran KAP maka kualitas audit yang dihasilkan akan semakin tinggi. Selain itu hasil penelitian ini juga sesuai dengan hasil penelitian Choi et al.(2010) dan Aronmwan (2013) yang juga membuktikan bahwa ukuran KAP memiliki pengaruh yang signifikan terhadap kualitas audit. Berdasarkan hasil pengujian hipotesis dan penelitian terdahulu yang sesuai maka dapat ditarik kesimpulan bahwa hipotesis keempat dapat diterima.

\section{Kualitas Audit Berpengaruh Positif Terhadap Audit Delay}

Pengujian selanjutnya dilakukan untuk melihat hubungan yang terjadi antara kualitas audit dan audit delay. Hal ini merupakan hal yang menarik karena kualitas audit dan audit delay memiliki hubungan yang erat. Berdasarkan pengiolahan data yang telah dilakukan, diperoleh hasil bahwa nilai koefisien yang dihasilkan adalah sebesar $-0,37$ dan $p$-value sebesar $<0,01$. Hasil tersebut memiliki makna bahwa apabila kualitas audit tersebut rendah maka tidak akan terjadi audit delay. Hal ini bisa saja terjadi karena apabila menginginkan kualitas audit yang semakin baik maka kecenderungan yang ada adalah terjadinya audit delay. Rentang waktu penyelesaian audit yang lebih cepat adalah cara KAP untuk mempertahankan reputasinya agar tidak kehilangan kepercayaan klien (Sunangsih, 2014). Namun, perusahaan memerlukan auditor yang berkualitas tinggi, agar kualitas laporan keuangan yang diaudit bagus. Tetapi untuk mengaudit laporan keuangan secara benar dan hasil auditnya bagus maka membutuhkan waktu yang cukup sehingga bisa saja terjadi audit delay. Setiap awal tahun, masih banyak perusahaan yang belum mempublikasikan laporan keuangan auditnya. Salah satu faktor yang menyebabkan keterlambatan publikasi ini adalah adanya audit delay yang terjadi. Informasi keuangan dan kinerja perusahaan akan lebih dapat dipercaya apabila telah menggunakan jasa KAP (Saputri, 2012). Berdasarkan hasil pengujian hipotesis serta didukung oleh penelitian terdahulu maka dapat disimpulkan bahwa hipotesis kelima diterima. 


\section{KESIMPULAN}

\section{Kesimpulan}

Secara umum tujuan penelitian ini adalah untuk mengetahui pengaruh antara independensi, kompetensi, pengalaman kerja terhadap kualitas audit, dan untuk mengetahui hubungan antara kualitas audit dengan audit delay. Berdasarkan pembentukan hipotesis dan pengujian yang telah dilakukan oleh peneliti, maka dapat disimpulkan beberapa hasil dari penelitian ini.

Hasil dari penelitian ini memperlihatkan bahwa independensi berpengaruh positif signifikan terhadap kualitas audit, sehingga dapat dikatakan bahwa hipotesis pertama dalam penelitian ini diterima. Hasil pengujian pada hipotesis kedua menunjukkan bahwa kompetensi berpengaruh positif signifikan terhadap kualitas audit, sehingga hipotesis kedua dalam penelitian ini juga diterima. Pengujian yang dilakukan pada hipotesis ketiga menunjukkan bahwa pengalaman kerja berpengaruh positif signifikan terhadap kualitas audit, sehingga hipotesis ketiga dalam peneltian ini diterima. Selain itu pengujian yang dilakukan pada hipotesis keempat juga menunjukkan bawah ukuran KAP berpengaruh positif signifikan terhadap kualitas audit, oleh karena itu hipotesis keempat dapat diterima. Hasil pengujian yang terakhir, yaitu untuk menguji hipotesis kelima, hasil dari pengujian hipotesis tersebut membuktikan bahwa audit delay berpengaruh positif signifikan terhadap kualitas audit. Hal ini membuktikan ahwa audit delay mampu memediasi variabel independensi, kompetensi, pengalaman kerja, dan ukuran kap terhadap kualitas audit.

\section{Saran}

Berdasarkan penelitian ini, untuk selalu menjaga kualitas audit yang dihasilkan oleh seorang auditor, sebaiknya auditor harus selalu memiliki sikap independensi terhadap profesinya. Tidak hanya sikap independensi saja yang harus dimiliki, namun seorang auditor juga harus memiliki kompetensi dalam profesinya, sehingga dapat melakukan proses pengauditan sesuai dengan aturan dan membuat laporan audit berdasarkan fakta yang dia temukan.

Jika ingin terus mendapatkan dan mempertahankan kepercayaan klien untuk selalu menggunakan jasanya, penting bagi Kantor Akuntan Publik untuk mempekerjakan atau merekrut auditor yang memiliki sikap independent, kompetensi yang baik, dan memiliki pengalaman yang cukup dalam mengaudit sebuah laporan keuangan perusahaan klien. Selain itu, Kantor Akuntan Publik yang tergolong masih kecil atau belum terkenal, ada baiknya jika selalu berusaha untuk meningkatkan jumlah klien, dan selalu memperbaiki kualitas kerja yang dihasilkan oleh para auditornya sehingga Kantor Akuntan Publik tersebut akan makin besar. Jika sebuah Kantor Akuntan Publik makin besar maka akan lebih mudah dipercaya oleh klien atau calon klien mengenai kualitas audit yang dihasilkan KAP tersebut.

\section{Keterbatasan \& Saran}

Berdasarkan penelitian yang telah dilakukan keterbatasan penelitian sebagai berikut: Pertama; sampel yang hanya berfokus dinas, badan, dan RSUD, penelitian ini tidak menggunakan keseluruhan SKPD yang ada di kabupaten Klaten. Saran untuk penelitian selanjutnya adalah dengan memperluas sampel penelitian karena semakin banyak sampel maka hasil penelitian akan semakin dapat digeneralisasi (Alharbi, 2014). Penelitian ini hanya meneliti variabel penyajian laporan keuangan, aksesibilitas dan sistem pengendalian internal. Saran untuk penelitian selanjutnya dengan menambahkan variabel misalnya umur pemerintah daerah, karena umur pemerintah daerah yang lama akan semakin berpengalaman dalam penyusunan laporan keuangan sehingga lebih transparan dan akuntabel (Naopal, Rahayu, \& Yudowati, 2017).

\section{DAFTAR PUSTAKA}

Abdul Halim. 1997. Auditing I (Dasar-Dasar Auditing Laporan Keuangan). Yogyakarta: YKPN.

Agoes, Sukrisno. 2004. Auditing (Pemeriksaan Akuntan) Oleh Kantor Akuntan Publik Jilid I. Lembaga Penerbit Fakultas Ekonomi Universitas Indonesia. Jakarta. 
Agung, Gusti, Rai. 2008. Audit Kinerja Pada Sektor Publik: Konsep Praktik Studi Kasus. Penerbit: Salemba Empat.

Agusti, Restu dan Nastia Putri Pertiwi. 2013. Pengaruh Kompetensi, Independensi, dan Profesionalisme terhadap Kualitas Audit (Studi Empiris pada Kantor Akuntan Publik Sumatera). Jurnal Ekonomi, Vol 21 (3).

Alim, M. Nizarul, Trisna Hapsari dan Lilil Purwanti. 2007. Pengaruh Kompetensi dan Independensi Terhadap Kualitas Audit Dengan Etika Auditor Sebagai Variabel Moderasi. SNA X. Makassar.

Anugerah, Rita dan Sony Harsono Akbar, 2014. Pengaruh Kompetensi, Kompleksitas Tugas Dan Skeptisme Profesional Terhadap Kualitas Audit. Jurnal Akuntansi . Vol. 02 No. 02. ISSN 2337-4314.

Arens, Alvin \& James. 2006. Auditing Edisi Indonesia, Alih bahasa oleh Amir Abadi Yusuf. Jakarta: Salemba Empat

Arens, Alvin A., Randal J. Elder, dan Mark S. Beasley, 2010, Auditing and Assurance Services: An Integrated Approach, Edisi 13, Pearson Education, Inc., New Jersey.

Arens, et al. 2008. Auditing and Assurance Service: An Integrated Approach. Edisi Dua Belas, Erlangga, Jakarta.

Aronmwan, Edosa Joshua et al. 2013. Audit Firm Reputation and Quality. European Journal of Business and Management, Vol. 05 (07)

Ashton, R., Wilingham, J., \& Elliot, R. 1987. An Empirical Analysis of Audit Delay. Journal of Accounting Research, Vol. 25, No. 2, 275-292.

Ashton, R., Willingham, J. J., \& Elliot, R. K. 1987. An Empirical Analysis of Audit Delay. 25(2).

Badjuri, Achmad. 2011. Faktor-faktor Yang Berpengaruh Terhadap Kualitas Audit Auditor Independen Pada Kantor Akuntan Publik (KAP) Di Jawa Tengah. Dinamika Keuangan dan Perbankan, November 2011, Volume 3 (2).

Choi, J.H., Kim, C., Kim, J.B., dan Y. Zang. 2010. Audit office Size, Audit Quality, and Audit Pricing. " Auditing: The Journal of Practice \& Theory, 29 (01),73-97.

Christiawan, Y.J. 2002. Kompetensi dan Independensi Akuntan Publik: Refleksi Hasil Penelitian Empiris. Journal Directory : Kumpulan Jurnal Akuntansi dan Keuangan Unika Petra. Vol. 4 / No. 2.

De Angelo, L.E. 1981. Auditor Independence, Low balling, And Disclosure Regulation.

Journal Of Accounting And Economics 3. Agustus.

Francis, J. R. and M. D. Yu. 2009. Big 4 Office Size and Audit Quality. The Accounting Review, 84 (5).

Hardiningsih, P. 2010. "Pengaruh Independensi, Corporate Governance, Kualitas Audit Terhadap Integritas Laporan Keuangan”. Kajian Akuntansi (ISSN 1979-4886), Vol. 2, No.1, Pebruari 2010, hal: 61-76.

Herliansyah, Yudhi dan Meifida Ilyas. 2006. Jurnal. Pengaruh Pengalaman Auditor Terhadap penggunaan Bukti Tidak Relevan Dalam Auditor Judgment. Simposium Nasional Akuntansi IX. Padang. 
Indah, Siti Nur Mawar. 2010. "Pengaruh Kompetensi dan Independensi Auditor Terhadap Kualitas Audit (Studi Empiris Pada Auditor KAP Di Semarang)". Skripsi Program Sarjana Fakultas Ekonomi Universitas Diponegoro.

Kartika Andi, 2009. Faktor-Faktor Yang Mempengaruhi Audit Delay di Indonesia (Studi Empiris Pada Perusahaan-Perusahaa LQ 45 Yang Terdaftar di Bursa Efek Jakarta), Jurnal Bisnis dan Ekonomi (JBE), Fakultas Ekonomi Universitas Stikubank Semarang.

Kartika, A. 2009. Faktor-Faktor yang Mempengaruhi Audit Delay di Indonesia. Jurnal Bisnis dan Ekonomi, Vol. 16 (1).

Kartika, A. 2011. Faktor-Faktor yang Mempengaruhi Audit Delay Pada Perusahaan Manufaktur yang Terdaftar di BEI. 3(2).

Lee, C.J., C. Liu, dan T. Wang. 1999. “The 150-hour Rule”. Journal of Accounting and Economics. 27 (2). pp. 203-228.

Lee,Tom \& Mary Stone.1995. "Competence and Independence: The Congenial Twins of Auditing ?", Journal of Busniess Finance and Accounting

Mayangsari, Sekar. 2003. Analisis Pengaruh Independensi, Kualitas Audit, Serta Mekanisme Corporate Governance Terhadap Integritas Laporan Keuangan. Symposium Nasional Akuntansi VI. Oktober.

Menteri Keuangan. 2008. Peraturan Menteri Keuangan Republik Indonesia Nomor 17/PMK.01/2008 pasal 3 tentang "Jasa Akuntan Publik". Jakarta.

Mulyadi, 2002, Auditing, Edisi keenam, Cetakan pertama , Jakarta: Salemba Empat

Nugraha. 2012. Pengaruh Tekanan Anggaran Waktu, Lokus Kendali (Locus of Control), dan Komitmen Profesional Terhadap Penurunan Kualitas Audit. Yogyakarta: Universitas Gajah Mada.

Pernyataan Standar Audit No.04 (SA 220)

Salim, A. R., Kamallah, \& Ilham, E. 2012. Pengaruh Pengalaman Kerja, Independensi, Kompetensi dan Integritas Terhadap Kualitas Audit.

Samsi, Nur, Akhmad Riduan dan Bambang Suryono. 2013. Pengaruh Pengalaman Kerja, Independensi, dan Kompetensi Terhadap Kualitas Hasil Audit: Etika Auditor Sebagai Variabel Moderasi. Jurnal Ilmu Riset Akuntansi, Vol 1 (2).

Saputri, Dewi Oviek. 2012. Analisis Faktor-Faktor yang Mempengaruhi Audit Delay (Studi Empiris pada Perusahaan yang Terdaftar di Bursa Efek Indonesia). Universitas Diponegoro. Semarang.

Sawan, Nedal dan Ihab Alsaqqa.2013. Audit firm size and quality: Does audit firm size influence audit quality in the Libyan oil industry?. African Journal of Business Management Vol. 7(3), pp. 213-226.

Sawyer, Lawrence B.2009.Internal Auditing.Buku Satu. Edisi Lima. Jakarta: Salemba Empat.

Siregar, Sylvia Veronica, Fitriany, Arie Wibowo, dan Viska Anggraita, "Rotasi dan Kualitas Audit: Evaluasi Atas Kebijakan Menteri Keuangan KMK No. 423/KMK.6/2002 Tentang Jasa Akuntan Publik", 2011.

Standar Profesional Akuntan Publik 2011 No. 1 tentang Standar Audit. 
Sunaningsih, Suci Nasehati. 2014. Faktor - Faktor Yang Berpengaruh Terhadap Audit Delay. (Studi Empiris pada Perusahaan Sektor Jasa yang Terdaftar di Bursa Efek Indonesia Periode Tahun 2011 dan 2012). Diponegoro Journal of Accounting. 3(2), h:1-11

Suyono, Eko. 2012. Deterrminant Factors Affecting The Audit Quality: An Indonesian Perspective. Global Review of Accounting and Finance, Vol.3 (2)

Triningsih, Sri. 2007. Indepensi Auditor dan Komitmen Organisasi Sebagai Mediasi Pengaruh Pemahaman Good Governance, Gaya Kepemimpinan dan Budaya Organisasi Terhadap Kinerja Auditor. SNA X. Makassar.

Wiratama, W. J., \& Budiartha, K. 2015. Pengaruh Indepedensi, Pengalaman Kerja, Due Professional Care dan Akuntabilitas Terhadap Kualitas Audit. E-Jurnal Akuntansi Universitas Udayana, Vol. $10(1)$

Yuliana, Emma, \& Dini Wahjoe Hapsari. 2013. Pengaruh Ukuran Kantor Akuntan Publik dan Audit Tenure Terhadap Kualitas Audit (Studi Empiris Pada Perusahaan Manufaktur 